\title{
REVIEW
}

\section{Management of cardiogenic shock complicating acute myocardial infarction: towards evidence based medical practice}

\author{
S G Williams, D J Wright, L B Tan
}

The treatment of cardiogenic shock is the ultimate challenge of our ability to manage patients presenting with acute myocardial infarction. Despite advances in the treatment of infarcts with thrombolysis, there has been no significant decrease in the incidence of cardiogenic shock, which has remained at $7-10 \%$ during the last 20 years. ${ }^{1-5}$ Hospital mortality was over $90 \%$ in the $1970 \mathrm{~s}^{6}$ and is still high, in the region of $45-80 \%$, in the 1990 s. $^{17-9}$ Attitudes towards treatment of cardiogenic shock range from resignation, providing supportive measures only, to aggressive intervention. In the era of evidence based medical practice, are there data to support adoption of either extreme of approach?

\section{Registry of cardiogenic shock patients}

The largest prospectively identified registry of patients with cardiogenic shock so far analysed is from the GUSTO-I (global utilisation of streptokinase and tissue plasminogen activator for occluded coronary arteries) trial. ${ }^{410} \mathrm{Of}$ the 41021 patients recruited into that study, $7.2 \%$ (2972) developed cardiogenic shock, with an overall 30 day mortality of $55 \% .^{8}$ For those undergoing coronary artery bypass grafting (CABG) the 30 day mortality was $29 \%$, and for those having percutaneous transluminal coronary angioplasty (PTCA) it was $22 \%$. On single factor comparison of one year mortality, the hazard ratio (after adjustments for baseline characteristics) for PTCA versus no PTCA was 0.81 (95\% confidence interval (CI), 0.71 to $0.94 ; \mathrm{p}<0.005)$, suggesting that there may be medium term benefit with the PTCA management strategy. However, patients were not randomly allocated to revascularisation or conservative treatment in that study, and the better PTCA outcome could reflect selection bias. The hazard ratio for $\mathrm{CABG}$ versus no $\mathrm{CABG}$ was 1.08 (95\% CI, 0.89 to $1.30 ; p=0.445)$. It is unclear why the 30 day mortality advantage of CABG was not mirrored at one year.

The SHOCK (should we emergently revascularise occluded coronaries for cardiogenic shock) registry ${ }^{5}$ showed that patients selected to undergo coronary angiography had an improved outcome irrespective of whether they were revascularised or not. This type of selection bias may also be true for those selected to receive PTCA or CABG in other observational studies.

Is prophylactic PTCA/CABG indicated?

Many uncontrolled observational studies assessing the role of coronary angioplasty or bypass surgery appear to advocate the interventional treatment approach. Of the 24 papers analysing the use of PTCA, involving 1257 patients, , $88^{11-31}$ the overall mortality was $44 \%$, as shown in table 1 ( $31 \%$ for successful PTCA and $81 \%$ for unsuccessful PTCA). Of the 28 papers reporting the effects of CABG on a total of 743 patients, ${ }^{582031-54}$ the overall mortality was $42 \%$ (table 2 ). It is claimed that these figures show a more favourable outcome for intervention in comparison with conservative treatment in historical or contemporaneous controls. However, apart from the probable selection of less severely ill patients for intervention, there is another potential bias in that positive results (in favour of intervention) are more likely to have been reported or published.

GUSTO-I: is an invasive strategy better? In the GUSTO-I cardiogenic shock subgroup analysis, ${ }^{8}$ it was suggested that the lower mortality in the American patient cohort "may have been due to the greater use of invasive diagnostic and therapeutic procedures". However, further analysis suggests that this observation also reflects selection bias. First, the fact that the American patients with cardiogenic shock who were not revascularised had a lower mortality than their non-American counterparts (hazard ratio 0.73, p < 0.001) strongly suggests that the American cardiogenic shock population was an intrinsically lower risk group. Second, despite uniform recruitment criteria into the thrombolysis GUSTO-I study, the incidence of cardiogenic shock was $6.1 \%$ in the non-USA countries and $8.3 \%$ in the USA, so that $36 \%$ more patients were defined as having cardiogenic shock in the American population. It is possible that a lower threshold for classifying patients into the cardiogenic shock category was used by the American investigators if the criteria employed were insufficiently strict (for example, shock secondary to hypotensive agents such as opiates or $\beta$ blockers was not excluded). Assuming
Dr Tan

Accepted 8 March 2000 
Table 1 Papers reporting the use of PTCA in cardiogenic shock after acute myocardial infarction

\begin{tabular}{|c|c|c|c|}
\hline Author & Year & $\begin{array}{l}\text { Number in } \\
\text { study }\end{array}$ & $\begin{array}{l}\text { Mortality } \\
(\%)\end{array}$ \\
\hline Heuser $^{11}$ & 1986 & 10 & 40 \\
\hline Disler $^{12}$ & 1987 & 07 & 57 \\
\hline Landin $^{13}$ & 1988 & 34 & 41 \\
\hline Laramee $^{14}$ & 1988 & 39 & 41 \\
\hline $\mathrm{Lee}^{15}$ & 1988 & 24 & 50 \\
\hline Verna $^{17}$ & 1989 & 07 & 14 \\
\hline Shawl ${ }^{18}$ & 1989 & 09 & 33 \\
\hline Meyer $^{19}$ & 1990 & 25 & 47 \\
\hline $\mathrm{Lee}^{16}$ & 1991 & 69 & 45 \\
\hline Bengston $^{20}$ & 1992 & 14 & 43 \\
\hline Gacioch $^{21}$ & 1992 & 25 & 44 \\
\hline $\mathrm{O}^{\prime} \mathrm{Neill}^{22}$ & 1992 & 27 & 30 \\
\hline Hibbard $^{23}$ & 1992 & 45 & 44 \\
\hline Moosvi $^{24}$ & 1992 & 38 & 47 \\
\hline Yamamoto $^{25}$ & 1992 & 26 & 62 \\
\hline Seydoux ${ }^{26}$ & 1992 & 21 & 43 \\
\hline Himbert $^{7}$ & 1994 & 18 & 78 \\
\hline Hochman $^{9}$ & 1995 & 55 & 60 \\
\hline Morrison $^{27}$ & 1995 & 17 & 53 \\
\hline Eltchaninoff ${ }^{28}$ & 1995 & 33 & 36 \\
\hline Holmes $^{4}$ & 1997 & 565 & 22 \\
\hline Antoniucci ${ }^{29}$ & 1998 & 66 & 26 \\
\hline Calton $^{30}$ & 1999 & 18 & 28 \\
\hline Perez-Castellano ${ }^{31}$ & 1999 & 65 & 71 \\
\hline Total & & 1257 & 44 \\
\hline
\end{tabular}

Table 2 Papers reporting the use of $C A B G$ in cardiogenic shock after acute myocardial infarction

\begin{tabular}{|c|c|c|c|}
\hline Author & Year & $\begin{array}{l}\text { Number in } \\
\text { study }\end{array}$ & $\begin{array}{l}\text { Mortality } \\
(\%)\end{array}$ \\
\hline Dunkman $^{32}$ & 1972 & 15 & 40 \\
\hline Mundth $^{33}$ & 1973 & 33 & 61 \\
\hline Miller $^{34}$ & 1974 & 12 & 58 \\
\hline Mills $^{35}$ & 1975 & 10 & 0 \\
\hline Cascade $^{36}$ & 1975 & 03 & 67 \\
\hline Willerson $^{37}$ & 1975 & 03 & 67 \\
\hline Keon $^{38}$ & 1977 & 21 & 67 \\
\hline Johnson $^{39}$ & 1977 & 05 & 60 \\
\hline Erich $^{40}$ & 1977 & 03 & 67 \\
\hline Bardet $^{41}$ & 1977 & 04 & 50 \\
\hline $\mathrm{O}^{\prime}$ Rourke $^{42}$ & 1979 & 06 & 67 \\
\hline Subramanian $^{43}$ & 1980 & 20 & 45 \\
\hline DeWood $^{44}$ & 1980 & 19 & 42 \\
\hline Kirklin $^{45}$ & 1985 & 04 & 0 \\
\hline Phillips $^{46}$ & 1986 & 34 & 24 \\
\hline $\mathrm{Laks}^{47}$ & 1986 & 50 & 30 \\
\hline Athanasuleas ${ }^{48}$ & 1987 & 13 & 62 \\
\hline Guyton $^{49}$ & 1987 & 09 & 22 \\
\hline Bolooki $^{50}$ & 1989 & 07 & 43 \\
\hline Beyersdorf ${ }^{51}$ & 1991 & 11 & 55 \\
\hline Bengston $^{20}$ & 1992 & 17 & 12 \\
\hline Allen ${ }^{52}$ & 1993 & 66 & 09 \\
\hline Quigley $^{53}$ & 1993 & 05 & 80 \\
\hline Himbert $^{7}$ & 1994 & 05 & 40 \\
\hline Hochman $^{9}$ & 1995 & 16 & 19 \\
\hline Holmes $^{4}$ & 1997 & 338 & 29 \\
\hline Donatelli $^{54}$ & 1997 & 08 & 50 \\
\hline Perez-Castellano ${ }^{31}$ & 1999 & 06 & 91 \\
\hline Total & & 743 & 45 \\
\hline
\end{tabular}

that the same percentage of patients with acute myocardial infarction (6.1\%) developed cardiogenic shock in the USA as in the other countries, the actual number of patients with cardiogenic shock in the American cohort would be less, and the mortality for the American patients with cardiogenic shock would then become $67.5 \%$-not very different from the figure of $66 \%$ obtained in the non-American cohort. ${ }^{55}$ The recommendation for more invasive diagnostic and therapeutic strategies for managing cardiogenic shock cannot be upheld on the basis of the GUSTO-I investigators' interpretation of their data.

\section{Consecutive patients revascularised}

Only two published studies have entered unselected consecutive patients with cardiogenic shock after acute myocardial infarction into a strategy of coronary angiography and revascularisation, and they came to opposite conclusions. The first of these ${ }^{7}$ showed mortalities for those with successful reperfusion of $70 \%$ and with unsuccessful reperfusion or medical treatment of $80 \%$; these figures were generally higher than in other cardiogenic shock cohorts. It would appear from that study that in unselected patients the mortality associated with revascularisation was not as low as suggested by previous reports with potential selection bias. In the other series ${ }^{29}$ where PTCA was performed in a consecutive cohort of patients, an inpatient hospital mortality of $26 \%$ was reported (17 of 66 patients). The success rate of PTCA was $94 \%$ and this group had an overall mortality of $21 \%$. The mortality in this study compares favourably with other series and this would seem to support an interventional approach to treatment. Although a consecutive series excludes preselection bias of those patients most likely to survive, the incidence of cardiogenic shock in this cohort was higher than in previous studies (66 of 364, or $18 \%$ of all patients admitted with acute myocardial infarction), which again raises the possibility that the physicians had used permissive criteria for diagnosing cardiogenic shock. Such conflicting outcomes suggest that it is essential to rely on randomised controlled trials to determine whether interventional strategies should be advocated for all patients with cardiogenic shock after acute myocardial infarction.

\section{Randomised controlled studies}

The SHOCK trial randomly allocated patients with cardiogenic shock to early revascularisation (PTCA or CABG) or medical treatment, and the results showed no significant difference in the primary end point of 30 day mortality between the two groups $(46.7 \%$ v $56.0 \%$, $\mathrm{p}=0.11) .{ }^{9}$ These results from the randomised cohort were considered to be representative of other non-randomised patients in the registry. The suggestion from previous uncontrolled studies that PTCA/CABG confers better outcome and should be offered to all patients with cardiogenic shock is not borne out by this randomised trial, and is likely to reflect selection biases in favour of intervention groups in observational studies.

The SMASH (Swiss multicenter angioplasty for shock) trial, comparing initial strategies of coronary angioplasty with medical treatment, also showed a non-significant mortality difference $(69 \%$ v $78 \%$; relative risk $0.88,95 \% \mathrm{CI}$, 0.6 to 1.2$).^{56}$ The comparatively higher mortality in this study reflected the inclusion of sicker patients, who remained hypotensive despite inotropic support and volume replacement. This study was terminated early because of difficulties in patient recruitment.

These two studies are the first well conducted randomised controlled trials of treatment in cardiogenic shock. The results have 
exposed the unreliability of previous uncontrolled trials that suggested that PTCA or CABG would result in a major reduction in mortality in patients with cardiogenic shock. In the light of such neutral controlled trial results, it is natural to try to find something positive in further analyses, but this process may be as treacherous as reliance on results from uncontrolled observational studies. Setting aside the result for the primary endpoint, and basing their view on the lower mortality observed in the revascularisation group at six months, the authors of the SHOCK trial concluded that "early revascularisation (should) be strongly considered for patients with acute myocardial infarction complicated by cardiogenic shock." This position is rather precarious if we note that between 30 days and six months after randomisation, there were only five extra deaths in the PTCA/CABG group and 10 in the medical treatment group. Overreliance on such small numbers may be risky. In the accompanying editorial, ${ }^{57}$ there was an attempt to make something positive out of "a negative trial," as shown by the statement that "the $17 \%$ relative reduction in overall mortality at 30 days . . . is clinically relevant and therapeutically worthwhile since it represents 93 lives saved per 1000 patients treated," while ignoring the fact that this could have been due to chance alone $(\mathrm{p}>0.05)$.

If angioplasty and bypass surgery in patients with cardiogenic shock were low risk procedures, then the above recommendations might well be adopted into routine clinical practice. However, it is known that the operative risks are substantial in such patients, and when the extensive infarct processes are completed, revascularisation is unlikely to achieve much myocardial salvage. When the considerable cost in terms of physical and emotional stress brought about by the interventions is also taken into account, the adoption of a blanket strategy of early revascularisation to all patients with cardiogenic shock must await more convincing evidence of benefit.

We are, however, unlikely to see many more large scale randomised controlled trials of revascularisation for cardiogenic shock in the future unless there is a major injection of research funding. Unlike trials of drug treatment in myocardial infarction, conducting controlled trials on patients with cardiogenic shock is notoriously difficult. For instance, the 302 patients in the SHOCK trial took most of the past decade to recruit, and by nearly half as many trialists; this contrasts greatly with nearly 200 times as many patients recruited in half the time in the contemporary ISIS- 4 trial (fourth international study of infarct survival). ${ }^{57 a}$ It is therefore crucial to formulate a rational approach to the management of cardiogenic shock based on all available information on the subject. Currently, it is safe to state that early revascularisation should be advocated in selected cases, but the question is how to select these cases.

\section{Diagnostic criteria}

As with any other clinical conditions, the first crucial step in management is arriving at the correct diagnosis. ${ }^{58}$ As illustrated above in the analysis of the subgroup with cardiogenic shock in the GUSTO-I trial, differences in diagnostic criteria can lead to important differences in outcome. They may also play a role in the differences in mortality in various study cohorts (for example, SHOCK versus SMASH trial results). In most of these studies the prespecified criteria for diagnosing cardiogenic shock did not exclude the contributory role of hypotensive agents (such as opiates or angiotensin converting enzyme (ACE) inhibitors) or negative inotropic agents ( $\beta$ blockers, verapamil), which are often used in patients with acute myocardial infarction. In some studies, the contribution of tachyarrhythmias, bradyarrhythmias, or relative hypovolaemia (for example, in infarction of the right ventricle) may have allowed the inclusion of patients with potentially reversible causes of shock, who tend to have a better prognosis. In non-randomised studies, other sources of bias may confound the results, such as the failure to exclude patients with cardiogenic shock who died before angiography, and allowing them to be included in the group treated conservatively; or failure to account for differences in the baseline characteristics of the group selected for intervention-these patients may be younger and have less co-morbid illness or previous infarction.

\section{How to select cases for cardiac interventions}

From our current understanding of the pathophysiological processes involved in cardiogenic shock, the data from the SHOCK and SMASH trials may now be used as a basis for formulating a rational approach to management. An obvious but key point in this consideration is that the most fundamental objective of revascularisation is to relieve coronary arterial stenoses in order to improve perfusion and function of the myocardial regions in jeopardy. Evidence of myocardial jeopardy and viability is vital for successful revascularisation. This implies that late presentation and delayed revascularisation after diagnosis will make the intervention less likely to be beneficial. Unfortunately cardiogenic shock often presents rather late after the onset of myocardial infarction. ${ }^{14} 9$ Those with early presentation (less than six hours after the onset of infarction) and with features suggestive of ongoing ischaemia should be seriously considered for revascularisation, whereas those with late presentation are likely to benefit from revascularisation only if significant amounts of myocardium can be shown to be in jeopardy and still salvageable.

The SHOCK data suggest that younger patients $(<75$ years old) are more likely to benefit from revascularisation. This observation is consistent with the concept that natural attrition throughout adult life effectively leads to the eventual loss of $35 \%$ of cardiomyocytes in the heart, ${ }^{59}$ while it is also known that cardiogenic shock often occurs once there is 
loss of more than $40 \%$ of left ventricular myocardium through infarction. ${ }^{60}$ Thus, comparatively, older patients have less room for myocardial loss before pump failure occurs and are more susceptible to cardiogenic shock with smaller infarcts; they are also less likely to have a sizeable amount of salvageable myocardium than their younger counterparts.

If death is the endpoint to prevent, then identifying the individual patients who are most likely to die will require an accurate and reliable predictive indicator. Using a logistic regression modelling technique, the GUSTO-I investigators showed that "cardiac output measurements were of greatest prognostic significance" even when demographic and clinical variables were included in the analysis. ${ }^{61}$ This is consistent with the concept that, in the absence of life threatening arrhythmia, the most important determinant of mortality is cardiac pump function, as it is inadequate pumping that leads to circulatory collapse and cardiogenic shock. In cardiogenic shock, a more important feature than the cardiac function at baseline resting states is the reserve pumping capability of the failing heart. ${ }^{62}{ }^{63}$ Availability of this mechanistic information alone would help clinicians to select, on an individual basis, which patients should receive invasive treatment. This information may be used in conjunction with the more probabilistic information contained in the risk factors derived from multivariate analysis of other patient cohorts. ${ }^{61}$

In a consecutive unselected series of cardiogenic shock patients, ${ }^{64}$ it has been shown that if the baseline resting cardiac power output (arterial pressure $\times$ flow output, expressed in watts) is below $0.4 \mathrm{~W}$ after optimising the filling pressures, none of these patients will survive on medical treatment alone; those with cardiac power output still falling below the normal resting level for an average sized adult $(<1 \mathrm{~W})$ with maximal inotropic stimulation were also found to be non-survivors with medical treatment alone. The reason why cardiac power output or left ventricular stroke work $^{64}$ are better indicators than cardiac output or other variables is because the function of the heart pump is not only to generate flow but also pressure, and these variables incorporate both flow and pressure generating capacity. ${ }^{62}{ }^{63}$ Because of the clear separation between the non-survivors (who had inadequate cardiac reserve at the time of evaluation) and survivors (with adequate reserve), it is possible to triage patients according to their cardiac reserve status. Patients with poor reserve are the ones who will need to be considered for aggressive interventions if death is to be prevented.

The question of which intervention is optimal requires further study, but the absence of myocardial contractile reserve suggests that such patients are unlikely to have enough viable myocardium for revascularisation to have a major impact on survival. Suitable patients would therefore require mechanical circulatory support $\mathrm{t}^{65-67}$ as a bridge to cardiac transplantation ${ }^{68-70}$ or, in a small proportion, to allow stunned myocardium to recover. ${ }^{71}{ }^{72}$ Ongoing studies such as HEROICS (how effective are revascularisation options in cardiogenic shock?) and TACTICS (thrombolysis and counterpulsation to improve cardiogenic shock survival) will provide further insight into these issues. On the other hand, if aggressive interventions are not indicated, then objective physiological information about prognosis is helpful in avoiding futile and undignified struggles against the inevitable.

Technologically, the measurement of cardiac reserve does not require unusually sophisticated equipment. As described previously, ${ }^{64}$ it requires measurement of pressures and cardiac output using Swan-Ganz catheter systems available in all modern coronary care or intensive care units. However, for clinicians without access to such equipment, a simple bedside rule of thumb may help: if the blood pressure on maximal inotropic stimulation fails to exceed $100 / 70 \mathrm{~mm} \mathrm{Hg}$ and the patient is still clinically hypoperfused (oliguric, peripherally shut down, diaphoretic), then it is highly unlikely that the cardiac output has exceeded $5.5 \mathrm{l} / \mathrm{min}$ to give a power output value of $>1 \mathrm{~W}$. Such patients would fall into the category of non-survivors on medical treatment alone.

Patients who are responsive to inotropic stimulation and show adequate cardiac reserve (power output $>1 \mathrm{~W}$ ), and who present early after the onset of acute myocardial infarction, may be suitable for early revascularisation to salvage the still viable myocardium. Alternatively, they may have extensive stunned myocardium that could recover in due course without revascularisation, given sustained inotropic support. $^{71}{ }^{72}$ Those who present late with cardiogenic shock and have adequate cardiac reserve may not require acute prophylactic revascularisation, because with optimal medical treatment these patients are likely to survive the acute episode, ${ }^{64}$ and interventions may be planned subsequently if indicated to prevent further cardiac events.

\section{Prevention is the best policy}

Once cardiogenic shock has occurred the prognosis is dire, even with revascularisation. ${ }^{9}$ Major efforts should therefore be directed towards preventing shock after the onset of acute myocardial infarction. ${ }^{73}$ Appropriate treatment of every infarct is a prerequisite in this task. There is a suggestion that, compared with thrombolysis, primary angioplasty reduces the incidence of eventual heart failure, ${ }^{74}$ but whether this will affect the incidence of cardiogenic shock is at present unknown. The use of stents and platelet inhibitors may further enhance the successes of primary angioplasty. ${ }^{29}{ }^{75-78}$

Prevention should also include identification of the preshock state followed by treatment aimed at preventing deterioration into cardiogenic shock-that is, relief of ischaemia, control and prevention of arrhythmias, optimisation of haemodynamic variables by inotropic support, and the use of glucose-insulinpotassium infusions to support viable myocardial function. ${ }^{79} 80$ 
A major objective of treating the preshock syndrome is to prevent the occurrence of a vicious cycle whereby systemic arterial hypotension leads to further coronary hypoperfusion, which in turn results in worse hypotension, and so on. Agents likely to aggravate this tendency are widely used in the treatment of acute myocardial infarction. Opiates, angiotensin converting enzyme (ACE) inhibitors, $\beta$ blockers, nitrates, and calcium antagonists need to be used very cautiously in these patients because they can precipitate cardiogenic shock. ${ }^{81}{ }^{82}$ It is important to highlight that treatment for cardiogenic shock (at the severe extreme of the spectrum of heart failure) is different from treatment for heart failure, because nowadays ACE inhibitors and $\beta$ blockers are indicated for the treatment of heart failure ${ }^{83-86}$ but should be avoided in true cardiogenic shock, and they may precipitate shock if the patient is in the preshock state. Right ventricular involvement in infarction has a poor prognosis $^{87}{ }^{88}$ and requires careful adjustments of right and left ventricular preloads with invasive monitoring.

\section{Conclusion}

The results of the SMASH and SHOCK studies have not suggested that there is an absolute indication to proceed with prophylactic revascularisation in patients with cardiogenic shock, but selected high risk patients who are likely to benefit from interventions should be diligently identified and offered appropriate intervention, either acutely or electively. Rather than relying on subjective impressions, physiological and objective means of selecting and categorising these patients should be adopted in clinical practice. A major thrust in therapeutic efforts should be directed at preventing the onset of cardiogenic shock if at all possible.

1 Goldberg RJ, Samad NA, Yarzebski J, et al. Temporal trends in cardiogenic shock complicating acute myocardial infarcin cardiogenic shock complicating acu
tion. $N$ Engl F Med 1999;340:1162-8.

2 Goldberg RJ, Gore JM, Alpert JS, et al. Cardiogenic shock after acute myocardial infarction: incidence and mortality from a community-wide perspective, 1975 to 1988 . N Eng 7 Med 1991;325:1117-22.

Califf RM, Bengtson JR. Cardiogenic shock. N Engl f Med 1994;330:1724-31.

4 Holmes DR, Califf RM, Van de Werf F, et al, for the GUSTO-1 investigators. Difference in countries' use of resources and clinical outcome for patients with cardio-
genic shock after myocardial infarction: results from the GUSTO trial. Lancet 1997;349:75-8.

5 Hochman JS, Sleeper LA, Godfrey E, et al, for the SHOCK trial study group. Should we emergently revacularise occluded coronaries for cardiogenic shock: an international randomised trial of emergency PTCA/CABG trial design. Am Heart f 1999; 137:313-21.

6 Resnekov L. Cardiogenic shock. Chest 1983;83:893-8.

7 Himbert D, Juliard JM, Steg PG, et al. Limits of reperfusion Himbert D, Juliard JM, Steg PG, et al. Limits of reperfusion therapy for immediate cardiogenic shock complicating

8 Holmes DR, Bates ER, Kleiman NS, et al, for the GUSTO-1 investigators. Contemporary reperfusion therapy for cardiogenic shock: the GUSTO-1 trial experience. 7 Am Coll Cardiol 1995;26:668-74.

9 Hochman JS, Boland J, Sleeper LA, et al, and the SHOCK registry investigators. Current spectrum of cardiogenic shock and effect of early revascularisation on mortality: results of an international registry. Circulation 1995;91: 873-81.

10 Berger PB, Holmes DR, Stebbins AL, et al, for the GUSTO-1 investigators. Impact of aggressive invasive catheterisation and revascularisation strategy on mortality in patients with cardiogenic shock in the global utilisation of streptokinase and tissue plasminogen activator for occluded coronary arteries (GUSTO-1) trial. An observational study. Circulation 1997;96:122-7.

11 Heuser RR, Maddoux GL, Goss JE, et al. Coronary angioplasty in the treatment of cardiogenic shock: the therapy of choice [abstract]. F Am Coll Cardiol 1986;7(suppl A):219A.
12 Disler L, Haitas B, Benjamin J, et al. Cardiogenic shock in evolving myocardial infarction: treatment by angioplasty and streptokinase. Heart Lung 1987;16:649-52.

13 Landin RJ, Rothbaum DA, Linnemeier TJ, et al. Hospital mortality of patients undergoing emergency angioplasty for acute myocardial infarction: relationship of mortality to cardiogenic shock and unsuccesful angioplasty [abstract]. Circulation 1988;78(SII): 9

14 Laramee LA, Rutherford BD, Ligon RW, et al. Coronary angioplasty for cardiogenic shock following myocardial infarction [abstract]. Circulation 1988;78(SII):615A.

15 Lee L, Erbel R, Brown TM, et al. Multicentre registry of angioplasty therapy of cardiogenic shock: initial and long term survival. f Am Coll Cardiol 1991;17:599-603.

16 Lee L, Bates ER, Pitt B, et al. Percutaneous transluminal coronary angioplasty improves survival in acute myocardial infarction complicated by cardiogenic shock. Circulation 1988;78:1345-51

17 Verna E, Repetto S, Boscarini M, et al. Emergency coronary angioplasty in patients with severe left ventricular dysfunction or cardiogenic shock after acute myocardial infarction. Eur Heart f 1989;10:958-66.

18 Shawl FA, Domanski MJ, Hernandez TJ, et al. Emergency percutaneous cardiopulmonary bypass support in cardiogenic shock from acute myocardial infarction. Am $\mathcal{F}$ Cardiol 1989;64:967-70.

19 Meyer P, Blanc P, Baudouy M, et al. Treatment of primary cardiogenic shock by coronary angioplasty during the acute phase of myocardial infarction. Arch Mal Coeur Vaiss 1990; 83:329-34

20 Bengston JR, Kaplan AJ, Pieper KS, et al. Prognosis in cardiogenic shock after acute myocardial infarction in the interventional era. $\mathcal{F}$ Am Coll Cardiol 1992;20:1482-9.

21 Gacioch GM, Ellis SG, Lee L, et al. Cardiogenic shock complicating acute myocardial infarction: the use of coronary angioplasty and the integration of the new support devices into patient management. F Am Coll Cardiol 1992; 19:647-53.

22 O'Neill WW. Angioplasty therapy of cardiogenic shock: are randomised trials necessary? 7 Am Coll Cardiol 1992;19: 915-17.

23 Hibbard MD, Holmes DR, Baily KR, et al. Percutaneous transluminal coronary angioplasty in patients with cardiogenic shock. f Am Coll Cardiol 1992;19:639-46.

24 Moosvi AR, Khaja F, Villanueva L, et al. Early revascularisation improves survival in cardiogenic shock complicating acute myocardial infarction. I Am Coll Cardiol 1992;19: 907-14.

25 Yamamoto $\mathrm{H}$, Hayashi Y, Oka Y, et al. Efficacy of percutaneous transluminal coronary angioplasty in patients with acute myocardial infarction complicated by cardiogenic shock. Fpn Circ f 1992;56:815-21.

26 Seydoux C, Goy JJ, Beuret P, et al. Effectiveness of percutaneous transluminal coronary angioplasty in cardiogenic shock during acute myocardial infarction. Am $\mathcal{f}$ Cardiol 1992;69:968-9.

27 Morrison D, Crowley ST, Bies R, et al. Systolic blood pressure response to percutaneous transluminal coronary angioplasty for cardiogenic shock. Am f Cardiol 1995;76: 313-14.

28 Eltchaninoff H, Simpfendorfer C, Franco I, et al. Early and 1 -year survival rates in acute myocardial infarction complicated by cardiogenic shock: a retrospective study comparing coronary angioplasty with medical treatment. Am Heart f 1995;130:459-64.

29 Antoniucci D, Valenti R, Santoro GM, et al. Systemic direct angioplasty and stent supported direct angioplasty therapy for cardiogenic shock complicating acute myocardial infarction: in-hospital and long term survival. $7 \mathrm{Am}$ Coll Cardiol 1998;31:294-300.

30 Calton R, Jaison TM, David T. Primary angioplasty for cardiogenic shock complicating acute myocardial infarction. Indian Heart f 1999;51:47-54.

1 Perez-Castellano N, Garcia E, Serrano JA, et al. Efficacy of invasive strategy for the management of acute myocardial nfarction complicated by cardiogenic shock. Am $\mathcal{F}$ Cardiol 1999;83:989-93.

32 Dunkman WB, Leinbach RC, Buckley MJ, et al. Clinical and haemodynamic results of intraaortic balloon pumping and surgery for cardiogenic shock. Circulation 1972;156: 465-77

33 Mundth ED, Buckley MJ, Leinbach RC, et al. Myocardial revascularisation for the treatment of cardiogenic shock complicating myocardial infarction. Surgery 1971;70:7887.

34 Miller MG, Weintraub RM, Hedley-White J, et al. Surgery for cardiogenic shock. Lancet 1974;ii:1342-5.

35 Mills NL, Ochsner JL, Bower PJ, et al. Coronary artery bypass for acute myocardial infarction. South Med F 1975; 68:1475-80.

36 Cascade PN, Wajszczuk WJ, Rubenfine M, et al. Patient selection for surgery in left ventricular power failure. Arch Surg 1975;110:1363-7.

37 Willerson JT, Curry GC, Watson J, et al. Intra-aortic balloon counterpulsation in patients with cardiogenic shock, medically refractory left ventricular failure and/or recurrent ventricular tachycardia. Am $\mathcal{f}$ Med 1975;58:183-91.

38 Keon WJ. New therapeutic approaches to acute myocardial infarction (MI) and its size: a surgical approach. Avd Exp Med Biol 1977;82:394-7.

39 Johnson SA, Scanlon PJ, Loeb HS, et al. Treatment of cardiogenic shock in myocardial infarction by intra-aortic counterpulsation and surgery. Am f Med 1977;62:687-92. 
40 Erich DA, Biddle TL, Kronenberg MW, et al. The haemodynamic response to intra-aortic balloon counterpulsation in patients with cardiogenic shock complicating

1 Bardet J, Masquet C, Kahn JC, et al. Clinical and haemody namic results of intra-aortic balloon counterpulsation and surgery for cardiogenic shock. Am Heart f 1977;93:280-8.

42 O'Rourke MF, Sammel N, Chang V. Arterial counterpulsation in severe refractory heart failure complicating acute myocardial infarction. Br Heart $\mathcal{f}$ 1979;41:308-16.

43 Subramanian VA, Roberts AF, Zerma MJ, et al. Cardiogenic shock following acute myocardial infarction: late functional results after emergency cardiac surgery. $N Y$ State $7 \mathrm{Med}$ 1980;80:947-52.

44 DeWood MA, Notske RN, Hensley GR, et al. Intraaortic balloon counterpulsation with and without reperfusion for cardiogenic shock. Circulation 1980;61:1105-12.

45 Kirklin JK, Blackstone EH, Zorn GL, et al. Intermediate term results of coronary artery bypass grafting for acute term results of coronary artery bypass grafting for acut

46 Phillips SJ, Zeff RH, Skinner JR, et al. Reperfusion protocol and results in 738 patients with evolving myocardial infarction. Ann Thorac Surg 1986;41:119-25.

47 Laks H, Rosenkranz E, Buckberg GD. Surgical treatment of cardiogenic shock after acute myocardial infarction. Circulation 1986;74(SIII): 11-16.

48 Athanasuleas CL, Geer DA, Arciniegas JG, et al. A reappraisal of surgical intervention for acute myocardial infarction. F Thoracic Cardiovascular Surg 1987;93:405-14

49 Guyton RA, Arcidi JM, Langford DA, et al. Emergency coronary bypass for cardiogenic shock. Circulation 1987;76 V22-7.

50 Bolooki H. Emergency cardiac procedures in patients with cardiogenic shock due to complications of coronary artery disease. Circulation 1989;79:1137-48.

51 Beyersdorf F, Sarai K, Maul FD, et al. Immediate functional benefits after controlled reperfusion during surgical revascularisation for acute coronary occlusion. $尹$ Thorac Cardiocularisation for acute coron
vasc Surg 1991;102:856-66.

52 Allen BS, Buckberg GD, Fontan FM, et al. Superiority of controlled surgical reperfusion versus percutaneous transcontrolled surgical reperfusion versus percutaneous trans-
luminal coronary angioplasty in acute coronary occlusion. luminal coronary angioplasty in acute coro
Thorac Cardiovasc Surg 1993;105:864-84.

53 Quigley RL, Milano CA, Smith R, et al. Prognosis and management of anterolateral myocardial infarction in patients with severe left main stem disease and cardiogenic shock: the left main shock syndrome. Circulation 1993;88: 65-70

54 Donatelli F, Benussi S, Triggiani M, et al. Surgical treatment for life threatening acute myocardial infarction: a prospective protocol. Eur F Cardiothorac Surg 1997;11:228-33.

55 Tan LB. Resources for cardiogenic shock. Lancet 1997;349: 951-2.

56 Urban P, Stauffer JC, Bleed D, et al. A randomized evaluation of early revascularization to treat shock complicating acute myocardial infarction. The (Swiss) Multicenter Trial of Angioplasty for Shock-(S)MASH [see comments]. Eur of Angioplasty for Shock

57 Ryan TJ. Early revascularization in cardiogenic shock-a positive view of a negative trial. $N$ Engl $\mathcal{F}$ Med 1999;341: $687-8$

57a ISIS-4 (Fourth International Study of Infarct Survival) Collaborative Group. ISIS-4: a randomised factorial trial assessing early oral captopril, oral mononitrate, and intravenous magnesium sulphate in 58080 patients with suspected acute myocardial infarction. Lancet 1995 345:669-85.

58 Houston MC, Thompson WL, Robertson D. Shock Diagnosis and management. Arch Intern Med 1984;144: 1433-9.

59 Olivetti G, Melissari M, Capasso JM, et al. Cardiomyopathy of the aging human heart. Myocyte loss and reactive cellular hypertrophy. Circ Res 1991;68:1560-8.

60 Page DL, Caulfield JB, Kastor JA, et al. Myocardial changes associated with cardiogenic shock. $N$ Engl F Med 1971;285 133-7.

61 Hasdai D, Holmes DR, Califf RM, et al. Cardiogenic shock complicating acute myocardial infarction: predictors of death. GUSTO Investigators. Global utilization of streptokinase and tissue-plasminogen activator for occluded tokinase and tissue-plasminogen activator for

62 Tan LB. Clinical and research implications of new concepts in the assessment of cardiac pumping performance in hear failure. Cardiovasc Res 1987;21:615-22.

63 Tan LB. Evaluation of cardiac dysfunction, cardiac reserve and inotropic response. Postgrad Med f 1991;67(suppl 1):S10-20.

64 Tan LB, Littler WA. Measurement of cardiac reserve in cardiogenic shock: implications for prognosis and management. Br Heart 7 1990;64:121-8.
65 Scheidt S, Collins M, Goldstein J, et al. Mechanical circlatory assisstance with the intraaortic balloon pump
and other counterpulsation devices. Prog Cardiovasc Dis 1982;25:55-76.

66 Moore CH, Rubin JM, Schnitzler RN, et al. Experience and directions using cardiopulmonary support in fifty-three consecutive cases. ASAIO Trans 1991;37:M340-2.

67 Rees MR, Browne T, Sivananthan UM, et al. Cardiac resuscitation with percutaneous cardiopulmonary support. Lancet 1992;340:513-14.

68 El-Banayosy A, Deng M, Loisance DY, et al. The European experience of Novacor left ventricular assist (LVAS) therapy as a bridge to transplant: a retrospective mult centre study. Eur f Cardiothorac Surg 1999;15:835-41.

69 McCarthy PM, Smedira NO, Vargo RL, et al. One hundred patients with the HeartMate left ventricular evolving concepts and technology. F Thorac Cardiovasc Surg 1998;115:904-12.

70 Champagnac D, Claudel JP, Chevalier P, et al. Primary cardiogenic shock during acute myocardial infarction: results of emergency cardiac transplantation. Eur Heart f 1993;14: $925-9$

71 Kurose M, Okamoto K, Sato T, et al. Emergency and longterm extracorporeal life support following acute myocardial infarction: rescue from severe cardiogenic shock related to stunned myocardium. Clin Cardiol 1994;17:552-7.

72 Smalling RW, Sweeney M, Lachterman B, et al. Transvalvular left ventricular assistance in cardiogenic shock secondary to acute myocardial infarction. Evidence for recovery
from near fatal myocardial stunning. $7 \mathrm{Am}$ Coll Cardiol 1994;23:637-44.

73 Geddes JS, Adgey AAJ, Pantridge JF. Prevention of cardiogenic shock. Am Heart f 1980;99:243-54.

74 Ottervanger JP, Liem A, de Boer MJ, et al. Limitation of myocardial infarct size after primary angioplasty: is a higher patency the only mechanism? Am Heart f 1999;137:116972 .

75 Webb JG, Carere RG, Hitton JD, et al. Usefulness of coronary stenting for cardiogenic shock. Am $\mathcal{F}$ Cardiol 1997;79: $81-4$

76 Suarez de Lezo J, Medina M, Pan M, et al. Intracoronary stent treatment in the early phase of cardiogenic shock [abstract]. Eur Heart F 1998;19:29A.

77 Silva JA, Nunez E, Vivekananthan K, et al. Cardiogenic shock complicating acute myocardial infarction: a comparison of primary angioplasty versus primary stenting in in-hospital outcomes [abstract]. F Am Coll Cardiol 1999;33: 368-9A.

78 Giri S, Mitchel JF, Kiernan FJ, et al. Adjunctive use of abciximab improves clinical outcomes in acute myocardial
infarction patients presenting with cardiogenic shock [abstract]. $\mathcal{F}$ Am Coll Cardiol 1999;33:12A

79 Diaz R, Paolasso EA, Piegas LS, et al. Metabolic modulation of acute myocardial infarction. The ECLA (Estudios Cardiologicos Latinoamerica) Collaborative Group. Circulation 1998;98:2227-34.

80 Fath-Ordoubadi F, Beatt KJ. Glucose-insulin-potassium therapy for treatment of acute myocardial infarction: an overview of randomized placebo-controlled trials [see comments]. Circulation 1997;96:1152-6.

81 Wu JP, Chen YT, Lee AY. Opioids in myocardial ischaemia: potentiating effects of dynorphin on ischaemic arrhythmia, bradycardia and cardiogenic shock following coronar artery occlusion in the rat. Eur Heart f 1993;14:1273-7.

82 Hall AS, Cooke GA, Tan LB. ACE inhibitors after myocardial infarction. Lancet 1994;343:1632-3.

83 CONSENSUS Trial Study Group. Effects of enalapril on mortality in severe congestive heart failure. Results of the Cooperative North Scandinavian Enalapril Survival Study (CONSENSUS). The CONSENSUS Trial Study Group. N Engl F Med 1987;316:1429-35.

84 AIRE Study Investigators. Effect of ramipril on mortality and morbidity of survivors of acute myocardial infarction with clinical evidence of heart failure. Lancet 1993;342: 821-8.

85 CIBIS II Investigators and Committees. The cardiac insufficiency bisoprolol study II (CIBIS-II): a randomised trial. Lancet 1999;353:9-13.

86 MERIT-HF Study Group. Effect of metoprolol CR/XL in chronic heart failure: metoprolol CR/XL randomised intervention trial in congestive heart failure (MERIT-HF). Lancet 1999;353:2001-7.

87 Serrano Junior CV, Ramires JA, Cesar LA, et al. Prognostic significance of right ventricular dysfunction in patients with acute inferior myocardial infarction and right ventricular involvement. Clin Cardiol 1995;18:199-205.

88 Zehender M, Kasper W, Kauder E, et al. Right ventricular infarction as an independent predictor of prognosis after acute inferior myocardial infarction. $N$ Engl f Med 1993;328:981-8. 